\title{
Agronomic performance and chemical composition of silage from corn hybrids
}

\section{grown in southern Rondonia}

\author{
Desempenho agronômico e composição química da sillagem de híbridos de milho cultivados na \\ região sul de Rondônia
}

Rendimiento agronómico y composición química del ensilaje de híbridos de maíz cultivados en la región sur de Rondônia

Érica de Oliveira Araújo

ORCID: https://orcid.org/0000-0003-1996-4849 Instituto Federal de Educação, Ciência e Tecnologia de Rondônia, Brazil

E-mail: erica.araujo@ifro.edu.br

Lizianne de Matos Emerick

ORCID: https://orcid.org/0000-0001-5414-5457 Instituto Federal de Educação, Ciência e Tecnologia de Rondônia, Brazil E-mail: lizianne.emerick@ifro.edu.br

José Vanor Felini Catânio

ORCID: https://orcid.org/0000-0001-9400-5555 Instituto Federal de Educação, Ciência e Tecnologia de Rondônia, Brazil E-mail: vanor.catanio@ifro.edu.br

Diogo de Souza Freitas

ORCID: https://orcid.org/0000-0002-2626-9564 Instituto Federal de Educação, Ciência e Tecnologia de Rondônia, Brazil E-mail: desouzafreitasdiogo@gmail.com

Aline Ottes Moreira

ORCID: https://orcid.org/0000-0003-3646-7289 Instituto Federal de Educação, Ciência e Tecnologia de Rondônia, Brazil E-mail: alineottesmoreira@gmail.com

Fernando de Souza Silva

ORCID: https://orcid.org/0000-0002-1874-4521 Instituto Federal de Educação, Ciência e Tecnologia de Rondônia, Brazil E-mail: fernandoo1997ss@gmail.com

Jiovane Anderson da Silva Ribeiro

ORCID: https://orcid.org/0000-0002-7204-3961 Instituto Federal de Educação, Ciência e Tecnologia de Rondônia, Brazil E-mail: jiovaneribeiro.ifro@gmail.com

\begin{abstract}
Corn is a widely used crop for silage. However, due to the changes introduced in recent genotypes, regional information related to the agronomic production behavior and the chemical composition of the silage produced becomes necessary for the appropriate technological development destined to agricultural and animal production in the Amazon region. With this premise, the present study aimed to evaluate the agronomic performance of corn hybrids cultivated for silage production and the chemical composition of the ensiled material. The experiment was conducted from October 2020 to March 2021, under field conditions, in the experimental area of the Federal Institute of Education, Science and Technology of Rondonia, Colorado do Oeste Campus, in the municipality of Colorado do Oeste, RO, Brazil. The experimental design used was completely randomized, composed of six corn hybrids (GNZ7210 VTPRO2, AG8480 VTPRO3, BM3073 VTPRO3, BM270 VTPRO2, BM3066 VTPRO3 and BM3077 VTPRO3) and five replicates, cultivated at spacing of $0.80 \mathrm{~m}$ between rows and $0.20 \mathrm{~m}$ between plants. There was variation in the agronomic performance of the commercial corn hybrids for the southern region of Rondônia. The silages produced from the six corn hybrids showed bromatological and chemical characteristics that characterize them as silages of very good quality, despite showing significant differences in the percentages of DM, MM, CP, NNH3/TN, NDF and ADF. The hybrid BM3073 PRO3 stood out for fresh matter yield, shoot N content and quality of the silage produced, which may result in the reduction of silage production costs.
\end{abstract}

Keywords: Zea mays; Cultivars; Conservation; Forage; Quality; Silage.

\section{Resumo}

O milho é uma cultura muito utilizada para ensilagem. Entretanto, devido as modificações introduzidas nos genótipos recentes, informações regionais, pertinentes ao comportamento agronômico produtivo e a composição química da 
silagem produzida, fazem-se necessário para o adequado desenvolvimento tecnológico destinado à produção agrícola e animal na região Amazônica. Nessa premissa, o presente trabalho teve por objetivo avaliar o desempenho agronômico de híbridos de milho cultivados para a produção de silagem e a composição química do material ensilado. O experimento foi conduzido no período de outubro de 2020 a março de 2021, em condições de campo, na área experimental do Instituto Federal de Educação, Ciência e Tecnologia de Rondônia, Campus Colorado do Oeste, no munícipio de Colorado do Oeste, RO. O delineamento experimental utilizado foi o inteiramente casualizado, composto por seis híbridos de milho (GNZ7210 VTPRO2, AG8480 VTPRO3, BM3073 VTPRO3, BM270 VTPRO2, BM3066 VTPRO3 e BM3077 VTPRO3) e cinco repetições, cultivados em espaçamento de 0.80m entre linhas e $0.20 \mathrm{~m}$ entre plantas. Houve variação quanto ao desempenho agronômico dos híbridos comerciais de milho para a região sul de Rondônia. As silagens produzidas a partir dos seis híbridos de milho apresentaram características bromatológicas e químicas que as caracterizam como silagens de muito boa qualidade, apesar de terem apresentado diferenças significativas nas porcentagens de MS, MM, PB, NH3/NT, FDN e FDA. O híbrido BM3073 PRO3 destacou-se quanto à produtividade de massa verde, teor de $\mathrm{N}$ na parte aérea e qualidade da silagem produzida, o que pode refletir na amortização dos custos de produção da silagem.

Palavras-chave: Zea mays; Cultivares; Conservação; Forragem; Qualidade; Silagem.

\section{Resumen}

El maíz es un cultivo ampliamente utilizado para el ensilaje. Sin embargo, debido a los cambios introducidos en los genotipos recientes, la información regional, pertinente al comportamiento agronómico productivo y a la composición química del ensilaje producido, es necesaria para el desarrollo tecnológico adecuado destinado a la producción agrícola y animal en la región amazónica. Sobre esta premisa, el presente trabajo tuvo como objetivo evaluar el desempeño agronómico de los híbridos de maíz cultivados para la producción de ensilaje y la composición química del material ensilado. El experimento se llevó a cabo de octubre de 2020 a marzo de 2021, en condiciones de campo, en el área experimental del Instituto Federal de Educación, Ciencia y Tecnología de Rondônia, Campus Colorado do Oeste, en el municipio de Western Colorado, RO. El diseño experimental utilizado fue completamente aleatorizado, compuesto por seis híbridos de maíz (GNZ7210 VTPRO2, AG8480 VTPRO3, BM3073 VTPRO3, BM270 VTPRO2, BM3066 VTPRO3 y BM3077 VTPRO3) y cinco réplicas, cultivadas en un espaciamiento de 0,80 m entre filas y 0,20 $\mathrm{m}$ entre plantas. Hubo variación en el rendimiento agronómico de los híbridos comerciales de maíz para la región sur de Rondônia. Los ensilados producidos a partir de los seis híbridos de maíz mostraron características bromatológicas y químicas que los caracterizan como ensilajes de muy buena calidad, aunque presentaron diferencias significativas en los porcentajes de DM, MM, PB, NH3/NT, FDN y ADF. El BM3073 PRO3 híbrido se destacó en términos de productividad de masa verde, contenido $\mathrm{n}$ en brotes y calidad de ensilaje producido, lo que puede reflejar la amortización de los costos de producción de ensilaje.

Palabras clave: Zea mays; Cultivares; Conservación; Forraje; Calidad; Ensilaje.

\section{Introduction}

The estimated area planted with corn in the 2020/2021 season was 19,873 million hectares with a production of 106 million tons (Conab, 2021), which places the country in a prominent position in the global agribusiness. In the North region, corn is one of the main crops in terms of planted area, with approximately 846,000 hectares, used in properties from subsistence cultivation to high levels of technology. In Rondônia, just over 212,000 hectares were cultivated in the 2020/2021 season, with a production of 1 million tons of corn (Conab, 2021), which allows the state to be among the three largest producers in the Northern region.

Corn is the most used crop for silage production in Brazil (Bernandes and Rêgo, 2014) and in other countries (Ferraretto et al. 2015), because it has high content of soluble carbohydrates and, when well-managed, can provide high dry matter production per hectare and high nutritional value (Ferrari Júnior et al. 2005). Thus, in order to select better corn hybrids for silage production, agronomic characteristics such as forage fresh and dry matter yield as well as morphological and bromatological composition of the plant should be taken into account, aiming at higher food production and dilution of production costs (Bastos et al. 2019; Santos et al. 2017).

Moraes et al. (2013) state that the quality and nutritional value of the ensiled material may be influenced by the structural composition of corn plants and by the production of grains, leaf and stem. Paziani et al. (2009) also comment that silage quality is influenced by the structural composition of the plant and should be a criterion to be considered in the choice of 
a hybrid, as well as its total production of fresh and dry matter. However, most breeding programs of corn seed companies have not followed the development of the silage market (Pereira Filho and Borghi, 2016), much less in the Amazon region.

However, regional information related to the agronomic production behavior and nutritional value of the different genetic materials of corn and to the chemical composition of the silage produced becomes necessary for the adequate technological development destined to agricultural and animal production in the Amazon region. With this premise, the present study aimed to evaluate the agronomic performance of corn hybrids cultivated for silage production and the chemical composition of the ensiled material.

\section{Material and Methods}

The experiment was conducted from October 2020 to March 2021, under field conditions, in the experimental area of the Federal Institute of Education, Science and Technology of Rondônia, Colorado do Oeste Campus, in the municipality of Colorado do Oeste, RO, Brazil, whose geographic coordinates are $13^{\circ} 06^{\prime} \mathrm{S}$ and $60^{\circ} 29^{\prime} \mathrm{W}$, with an average altitude of 407 meters. According to Köppen's classification, the climate is Awa, warm and humid tropical with two well-defined seasons. Average temperature and precipitation data during the experiment were obtained from the database of the National Institute of Meteorology (Figure 1), and data of the chemical characterization of the soil in the 0-20 cm layer were obtained from samples collected prior to experiment installation (Table 1). Based on the results of the soil chemical analysis, liming was performed 3 days prior to sowing in order to raise the base saturation to $70 \%$.

Figure 1. Monthly averages of precipitation $(\mathrm{mm})$ and temperature $\left({ }^{\circ} \mathrm{C}\right)$, recorded at the weather station of the National Institute of Meteorology, from October 2020 to March 2021.

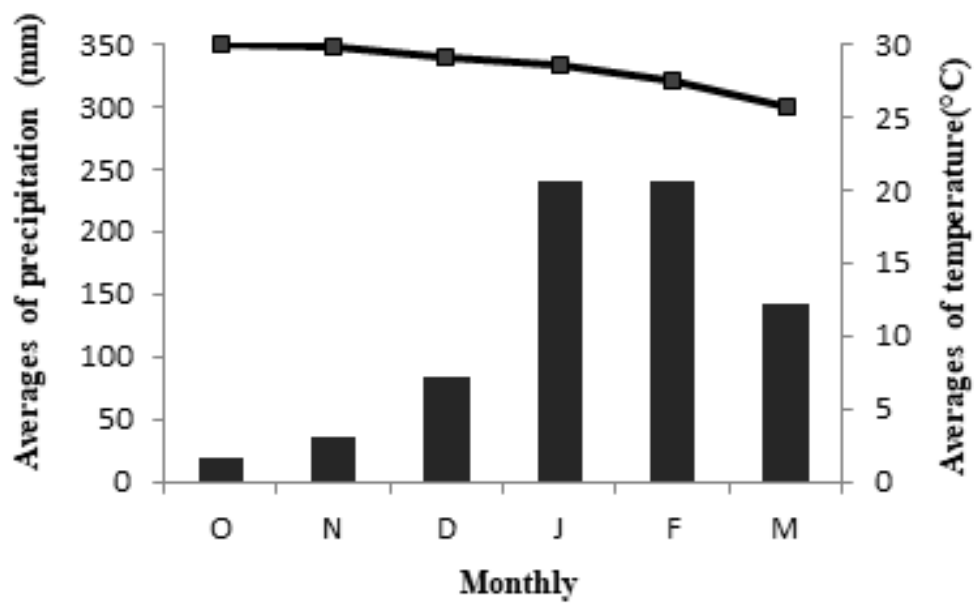

Source: Authors.

Table 1. Chemical attributes of the soil at different depths prior to experiment installation.

\begin{tabular}{|c|c|c|c|c|c|c|c|c|c|c|c|c|}
\hline \multirow{3}{*}{$\begin{array}{l}\text { Depth } \\
(\mathrm{cm})\end{array}$} & & & & & & & & & & & & $\mathrm{V}$ \\
\hline & $\mathrm{MO}$ & $\mathrm{CO}$ & $\mathrm{pH}$ & $\mathrm{P}$ & $\mathrm{K}$ & $\mathrm{Ca}$ & $\mathrm{Mg}$ & $\mathrm{H}+\mathrm{Al}$ & $\mathrm{Al}$ & SB & CTC & \multirow[b]{2}{*}{$(\%)$} \\
\hline & \multicolumn{2}{|c|}{$\mathrm{g} / \mathrm{kg}$} & $\mathrm{CaCl}_{2}$ & \multicolumn{3}{|c|}{$\mathrm{mg} / \mathrm{dm}^{-3}$} & 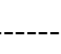 & -------cr & $/ \mathrm{dm}$ & -- & -- & \\
\hline $0-20$ & 21 & 12.2 & 5.1 & 1.9 & 72 & 3 & 0.3 & 3.3 & 0 & 4.6 & 7.9 & 58 \\
\hline
\end{tabular}


The experimental design used was completely randomized, composed of six corn hybrids (GNZ7210 VTPRO2, AG8480 VTPRO3, BM3073 VTPRO3, BM270 VTPRO2, BM3066 VTPRO3 and BM3077 VTPRO3) and five replicates, totaling 30 experimental units.

Table 2. Agronomic characteristics and suitable uses of different corn hybrids.

\begin{tabular}{cccccc}
\hline Hybrids & Fitness & Cycle & \multicolumn{3}{c}{ Tolerance } \\
& & & Pests & Diseases & Glyphosate \\
\hline GNZ 7210 VTPRO2 & Grains/silage & Early & Yes & Yes & Yes \\
AG 8480 VTPRO3 & Grains/silage & Early & & Yes & Yes \\
BM 3073 VTPRO3 & Silage & Superearly & Yes & Yes & Yes \\
BM 270 VTPRO2 & Grains/silage & Early & Yes & Yes & Yes \\
BM 3066 VTPRO3 & Silage & Early & Yes & Yes & Sim \\
BM 3077 VTPRO3 & Silage & Superearly & Yes & Yes & Sim \\
\hline
\end{tabular}

*VTPRO2 - Tolerance to insects of the order lepidoptera and the herbicide Glyphosate. *VTPRO3- Protection of the corn root against the attack of Diabrotica speciosa (pin larva), as well as tolerance to insects of the order lepidoptera and the herbicide Glyphosate.

Source: Geneze, Agroceres and Biomatrix (2021).

The experiment was implemented with previous application of glyphosate non-selective herbicide $(2.5 \mathrm{~L} / \mathrm{ha})$, diluted in $200 \mathrm{~L} / \mathrm{ha}$, for the control of spontaneous plants. Soil tillage consisted of harrowing up to $15 \mathrm{~cm}$ deep. Planting and fertilization furrows were mechanically opened at depths between 5 and $7 \mathrm{~cm}$, according to the spacing determined. The different corn hybrids were sown using a planter-fertilizer machine, at spacing of $0.80 \mathrm{~m}$ between rows and $0.20 \mathrm{~m}$ between plants. Each experimental unit was 7 meters wide and 10 meters long, considering the central rows as the useful area of each plot, disregarding $0.50 \mathrm{~m}$ on each end of the plot.

At the time of sowing, basal fertilization was carried out broadcast, with subsequent incorporation, at dose of $400 \mathrm{~kg}$ $\mathrm{ha}^{-1}$, using 4-30-16 formulation ( $\left.\mathrm{N}-\mathrm{P}_{2} \mathrm{O}_{5}-\mathrm{K}_{2} \mathrm{O}\right)$, while top-dressing nitrogen fertilization consisted of $217 \mathrm{~kg} \mathrm{ha}^{-1}$ of N, applied in the form of urea (45\%), in the total area of the plot, split into two applications of equal amounts, in the phenological stages of development V4 and V7, respectively. After plant emergence, herbicides were applied to control weeds after corn emergence, with glyphosate (4 L/ha diluted in $200 \mathrm{~L} / \mathrm{ha}$ ) applied in hybrids with resistance to this herbicide. Dichelops melacanthus (Green-belly stink bug) was controlled with the application of the insecticide Engeo Pleno S ( $250 \mathrm{~mL} / \mathrm{ha}$ diluted in 200 L/ha), whereas Cercospora zeae-maydis (Gray leaf spot) and Puccinia polysora (Southern rust) were controlled with the application of the fungicide Opera (1 L/ha diluted in $200 \mathrm{~L} / \mathrm{ha})$. The other cultural practices were performed as recommended for the crop.

In the phenological stage R4, when the grains showed texture with an aspect varying between milk and dough, the whole plant was harvested, selecting a strip of 4 linear meters within one of the planting rows, from which the plants were cut at $0.20 \mathrm{~m}$ height from the ground. To determine the production components, five representative ears per plot were sampled and the following parameters were evaluated: ear mass with straw, ear mass without straw, ear length, ear base diameter, number of grains per ear and number of grain rows per ear. In the plant, the following parameters were evaluated: plant height, ear attachment height, stem diameter near soil level and stem diameter above and below the main ear. Plant height was measured considering the distance from the point where the cut was made to the ligula of the last expanded leaf of the top (Ritchie et al. 1993), while ear attachment height was measured considering the distance from the point where the cut was made to the node where the ear was attached. Values of $0.20 \mathrm{~m}$ referring to the height at which the plant was cut were added to the values of 
height. Average stem thickness was determined at the cutting point and at two other points just below and above the node where the main ear was attached, using a digital caliper. Fresh matter yield was estimated after the plants were cut at $0.20 \mathrm{~m}$ height from the soil, by weighing the 18 plants present in 4 linear meters and then estimating the production per hectare. To determine the macronutrient contents in the shoots, two plants per plot were sampled, weighed on a precision scale and dried in a forced air circulation oven, at $65{ }^{\circ} \mathrm{C}$ for 72 hours to obtain the dry matter. Subsequently, the dry matter of the samples was ground and subjected to sulfuric and nitric-perchloric digestion to determine the contents of $\mathrm{N}, \mathrm{P}, \mathrm{K}, \mathrm{Ca}, \mathrm{Mg}$ and $\mathrm{S}$ according to the methodology described in Embrapa (2009).

In the second step, the remaining material in the useful area of each experimental unit in a strip of 4 linear meters was chopped in a manual silage machine, to prepare the silage, with average particle size of 2-3 cm. The chopped forage was homogenized and vacuum-ensiled in a volume of $500 \mathrm{~g}$ into transparent plastic bags, covered by a black plastic bag to avoid light and kept in a dark environment. After the fermentation period of 60 days, the plastic silos were opened and samples were collected to determine dry matter, crude protein, neutral detergent fiber, acid detergent fiber, N-NH3/TN, pH, lignin and starch.

The samples of the material were weighed and pre-dried in a forced air circulation oven at $65{ }^{\circ} \mathrm{C}$ for 72 hours, removed and weighed again to determine the dry matter content and then processed in a Wiley-type mill, with 1-mm-mesh sieve. A fraction of each silage sample was frozen when fresh and subsequently crushed and used for $\mathrm{pH}$ analysis, using digital potentiometer (Digimed). Pre-dried silage samples were analyzed for the total dry matter (DM) content, determined in an oven at $105{ }^{\circ} \mathrm{C}$, total nitrogen (TN) by the micro Kjeldahl method, multiplying the value by the factor 6.25 to obtain the crude protein (CP), and mineral matter (MM) content by incineration. Neutral detergent fiber (NDF) and acid detergent fiber (ADF), as well as lignin (LIG) and starch (ST) contents were determined according to Aoac (1995) and Silva and Queiroz (2006).

After all the analyses, the data were subjected to the Shapiro-Wilk residual normality test and then to analysis of variance by $\mathrm{F}$ test; when the parameters showed a significant difference, Tukey test at $5 \%$ probability level was applied to compare the means, using the statistical program Sisvar.

\section{Results}

\section{Agronomic performance of corn hybrids}

The results showed significant effects $(\mathrm{p} \leq 0.05)$ on plant height, ear attachment height, stem diameter, diameter below ear, ear length, ear diameter, number of grains per ear, number of grain rows per ear and fresh matter yield in response to the different corn hybrids cultivated for silage production (Table 3). 
Table 3. Agronomic performance of different corn hybrids cultivated for silage production.

\begin{tabular}{|c|c|c|c|c|}
\hline Hybrids & $\mathrm{PH}$ & EIH & ST & DBE \\
\hline AG 8480 PRO3 & $217.7 \mathrm{~b}$ & $96.88 \mathrm{c}$ & $20.85 \mathrm{~b}$ & $15.74 \mathrm{~b}$ \\
\hline AGZ 7210 PRO2 & $223.6 \mathrm{~b}$ & $112.28 \mathrm{~b}$ & $21.74 \mathrm{~b}$ & $16.00 \mathrm{~b}$ \\
\hline BM 270 PRO2 & $229.96 \mathrm{~b}$ & $114.24 \mathrm{~b}$ & $22.67 \mathrm{ab}$ & $17.56 \mathrm{ab}$ \\
\hline BM 3066 PRO3 & $233.88 \mathrm{~b}$ & $116.58 \mathrm{~b}$ & $20.66 \mathrm{~b}$ & $15.62 \mathrm{~b}$ \\
\hline BM 3073 PRO3 & $258.3 \mathrm{a}$ & $133.04 \mathrm{a}$ & $23.66 \mathrm{a}$ & $18.12 \mathrm{a}$ \\
\hline BM 3077 PRO3 & $254.91 \mathrm{a}$ & $134.27 \mathrm{a}$ & $23.52 \mathrm{a}$ & $18.76 \mathrm{a}$ \\
\hline Means & 236.39 & 117.88 & 22.18 & 16.96 \\
\hline $\mathrm{CV}(\%)$ & 3.98 & 7.43 & 5.38 & 6.00 \\
\hline Hybrids & $\mathrm{EC}$ & ED & NGF & NG \\
\hline AG 8480 PRO3 & $21.07 \mathrm{a}$ & $49.75 \mathrm{c}$ & $15.18 \mathrm{c}$ & $491.91 \mathrm{c}$ \\
\hline AGZ 7210 PRO2 & $19.33 \mathrm{~b}$ & $51.11 \mathrm{~b}$ & $16.49 \mathrm{~b}$ & $552.28 \mathrm{bc}$ \\
\hline BM 270 PRO2 & $18.82 \mathrm{~b}$ & $52.32 \mathrm{~b}$ & $19.52 \mathrm{a}$ & $643.21 \mathrm{a}$ \\
\hline BM 3066 PRO3 & $17.36 \mathrm{c}$ & $55.94 \mathrm{a}$ & $18.52 \mathrm{ab}$ & $598.15 \mathrm{ab}$ \\
\hline BM 3073 PRO3 & $19.65 \mathrm{~b}$ & $51.79 \mathrm{~b}$ & 20.24 a & $683.12 \mathrm{a}$ \\
\hline BM 3077 PRO3 & $19 ., 92 \mathrm{~b}$ & $51.28 \mathrm{~b}$ & $17.08 \mathrm{~b}$ & $603.92 \mathrm{ab}$ \\
\hline Means & 19.35 & 52.03 & 17.83 & 595.43 \\
\hline $\mathrm{CV}(\%)$ & 4.19 & 3.35 & 9.27 & 4.63 \\
\hline
\end{tabular}

* Means followed by equal letters in columns do not differ from each other by tukey test at 5\% probability. PH (Plant height), EIH (ear insertion height), ST(stem diameter), DBE (diameter below the ear), EC (ear length), ED (ear diameter), NGF (number of grain row per ear) and NG (number of grains per ear).

Source: Authors.

Plant height was different among the hybrids; BM3073 PRO3 and BM 3077 PRO3 had taller plants, while the other hybrids had shorter plants. Therefore, the other hybrids showed intermediate height (Table 3). On average, plants of the hybrids BM3073 PRO3 and BM3077 PRO3 were $256.60 \mathrm{~cm}$ tall, that is, a value $13.48 \%$ higher compared to the average of plants of the hybrids AG8480 PRO3, AGZ 7210 PRO2, BM270 PRO2 and BM 3066 PRO3. Ear attachment height was also different among the hybrids; BM3073 PRO3 and BM3077 PRO3 had plants with greater ear height, unlike plants of AG8480 PRO3, which produced ears with lower height. For the other hybrids, the values were intermediate and did not differ statistically from each other (Table 3). The average ear attachment height of the hybrids BM3073 PRO3 and BM3077 PRO3 was $133.65 \mathrm{~cm}$, that is, $37.95 \%$ greater than that of the AG8480 PRO3 hybrid, which had the lowest height. For stem diameter and stem diameter below the ear attachment point, plants of the hybrids BM3073 PRO3 and BM3077 PRO3 had the thickest stems, differing statistically from the hybrids AG8480 PRO3, AGZ 7210 PRO2 and BM 3066 PRO3, which had thinner stems (Table 3).

In the evaluation of the production components, the hybrids AG8480 PRO3 and BM3066 PRO3 produced ears with the greatest and shortest lengths, respectively, while the others did not differ statistically from each other (Table 3). When ear base diameter was evaluated, the results were inverse and proportional, that is, the hybrid AG8480 PRO3 had ears with smaller base diameter, while BM3066 PRO3 produced ears with a larger base diameter (Table 3). The ear length of the hybrids AG8480 PRO3 and BM3066 PRO3 ranged between $21.07 \mathrm{~cm}$ and $17.33 \mathrm{~cm}$, respectively; while ear base diameter varied between 49.75 and $55.94 \mathrm{~mm}$, respectively. For the number of rows in each ear and number of grains per ear, BM270 PRO2 and BM3077 PRO3 were the hybrids that stood out with the best values, while AG8480 PRO3 showed the worst performance for the two variables studied (Table 3). Thus, the averages of the number of grain rows and number of grains per ear of the 
hybrids BM270 PRO2 and BM3077 PRO3 were $30.96 \%$ and 34.81\%, respectively, higher than that of AG8480 PRO3. The other hybrids obtained intermediate values.

As for fresh matter production, the highest yield per hectare was obtained by the hybrids BM270 PRO2 and BM3073 PRO3, whose values were $59950 \mathrm{~kg} / \mathrm{ha}$ and $60937 \mathrm{~kg} / \mathrm{ha}$, respectively (Figure 2), with a positive correlation between plant height, number of grains per ear and higher fresh matter production for the hybrids, especially BM3073 PRO3, because the roughage produced by this hybrid contained significant values of $\mathrm{CP}, \mathrm{N}-\mathrm{NH} 3 / \mathrm{TN}$, NDF and ADF, combining quality and quantity (Figure 6A and Figure 6B).

Figure 2. Yield of different corn hybrids cultivated for silage production. *Means followed by equal letters on bars do not differ from each other by Tukey test at 5\% probability level.

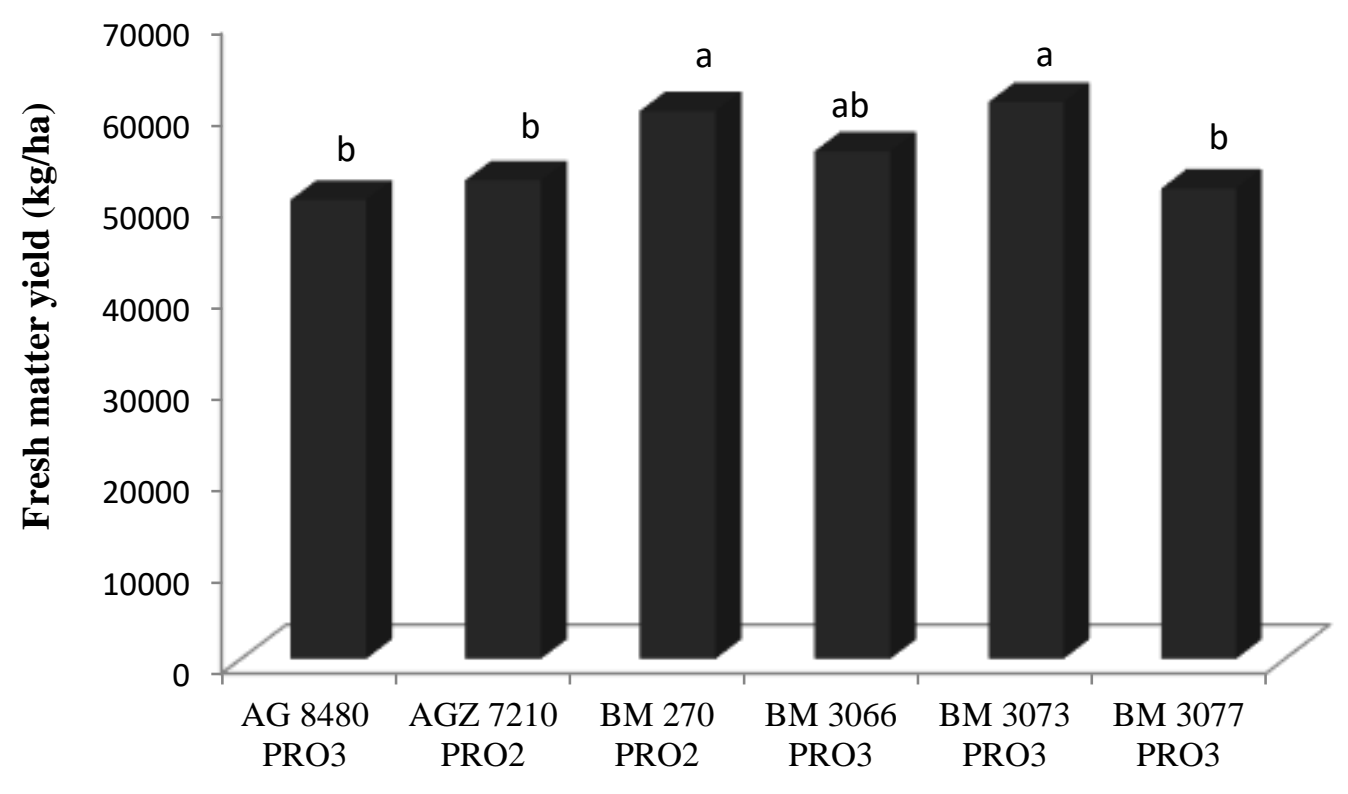

Source: Authors.

The analysis of variance for nutrient contents in the shoots of the different corn hybrids cultivated for silage production was significant $(\mathrm{p}<0.05)$ for nitrogen $(\mathrm{N})$, phosphorus $(\mathrm{P})$ and calcium $(\mathrm{Ca})$, with coefficients of variation on the order of $15.88 \%, 15.12 \%$ and $26.46 \%$, respectively, while the contents of potassium $(\mathrm{K})$ magnesium $(\mathrm{Mg})$ and sulfur $(\mathrm{S})$ showed no significant difference among the corn hybrids.

The hybrids BM3073 PRO3 and AG8480 PRO3 were more efficient regarding the accumulation of $\mathrm{N}$ and P, respectively, in the dry matter of shoots (without ear), differing statistically from the other materials (Figure 3A and Figure 3B), whereas the hybrids BM270 PRO2, BM3066 PRO3 and BM3077 PRO3 were superior in terms of calcium accumulation, not differing statistically from each other (Figure 4). 
Figure 3. $\mathrm{N}$ and $\mathrm{P}$ contents in the shoots of different corn hybrids cultivated for silage production. *Means followed by equal letters on bars do not differ from each other by Tukey test at $5 \%$ probability level.
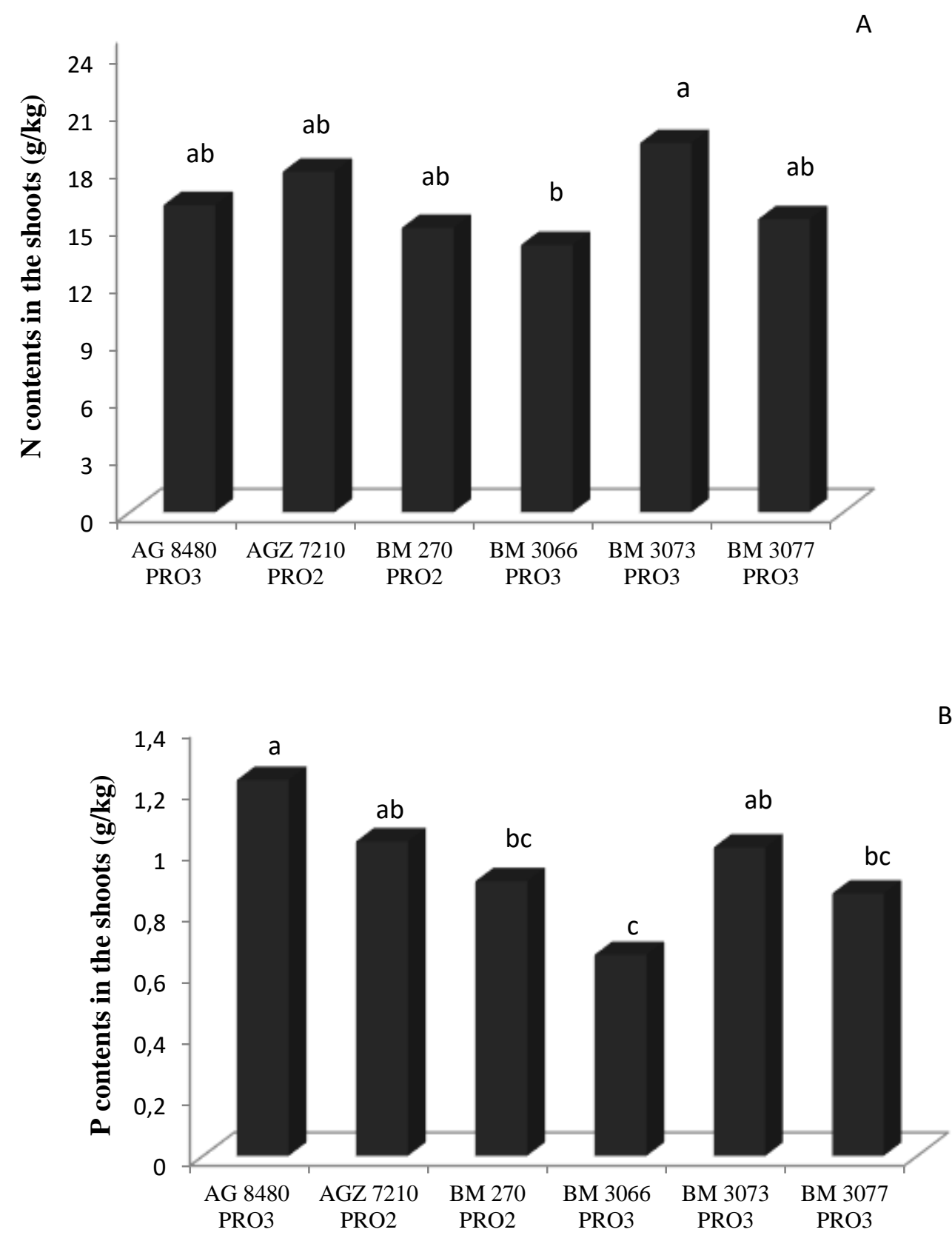

Source: Authors. 
Figure 4. Ca content in the shoots of different corn hybrids cultivated for silage production. *Means followed by equal letters on bars do not differ from each other by Tukey test at $5 \%$ probability level.

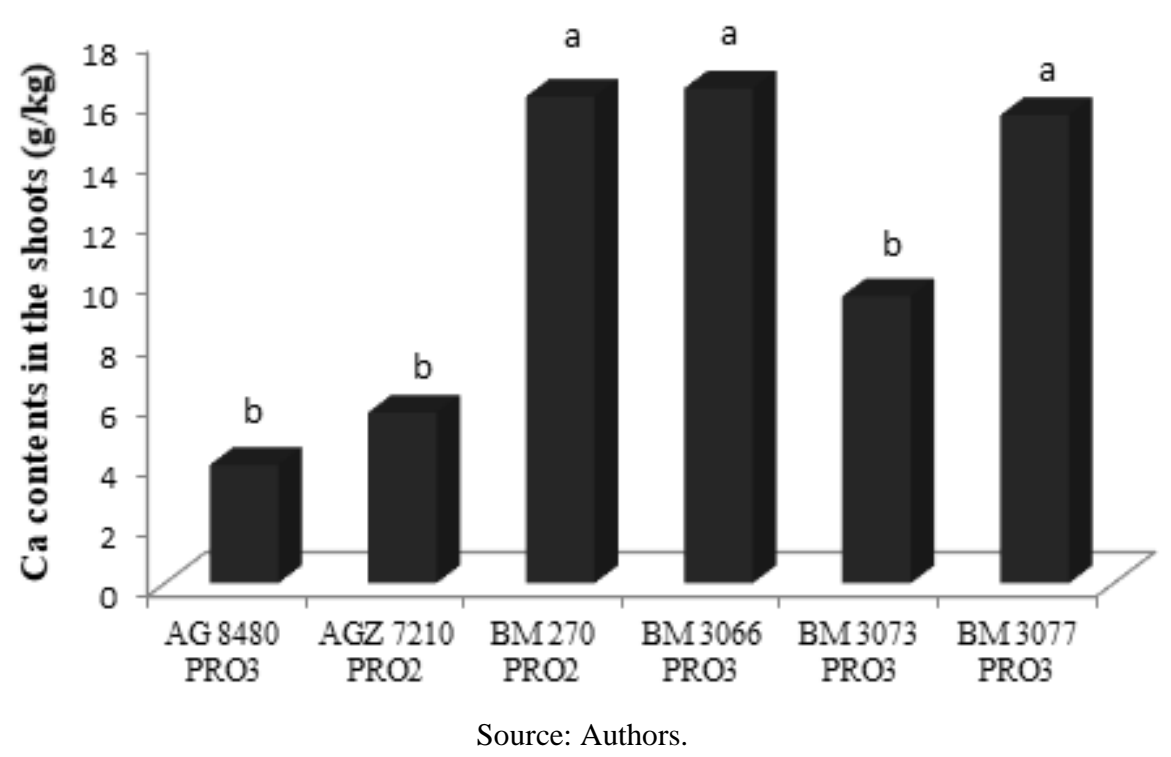

\section{Chemical composition of silage}

From the chemical analysis of the silages from the different corn hybrids, there was a significant effect $(\mathrm{p}<0.05)$ on the contents of dry matter (DM), mineral matter (MM), crude protein (CP), N-NH3/TN, neutral detergent fiber (NDF) and acid detergent fiber (ADF), with coefficients of variation of $2.79 \%, 5.68 \%, 3.26 \%, 14.63 \%, 2.10 \%$ and $10.02 \%$, respectively, while the $\mathrm{pH}$ values remained at an average of 3.76, with no statistical difference between the silages.

The hybrids AG8480 PRO3 and AGZ7210 PRO2 showed higher potentials for silage DM content, with average contents on the order of $30 \%$, differing statistically from the others $(\mathrm{p}<0.05)$, which had silages with DM contents between $25 \%$ and $28 \%$ (Figure 5). The contents of mineral matter (MM), crude protein (CP) and N-NH3/TN in the silages obtained from the six different corn hybrids were on average $4.69 \%, 6.61 \%$ and $2.04 \%$, respectively (Figure 6A) and differed statistically from each other $(\mathrm{p}<0.05)$, and the values obtained are compatible with those found in the literature. It is worth pointing out that the hybrids BM3073 PRO3 and BM3077 PRO3 had the highest crude protein and N-NH3/TN contents in the silages (Figure 6A), indicating that their quality is very good.

There was a significant difference $(\mathrm{p}<0.05)$ between the corn silages for neutral detergent fiber (NDF) and acid detergent fiber (ADF) contents; all hybrids studied showed NDF within the ideal range to stimulate the consumption of DM by animals, and the silages produced by the hybrids BM3073 PRO3 and BM3077 PRO3 contained the highest contents of NDF and ADF, with averages on the order of $37 \%$ and $18 \%$, respectively, while the other hybrids had NDF and ADF contents below the above-mentioned values (Figure 6B). It can be observed that the NDF and ADF contents for the hybrids BM3073 PRO3 and BM3077 PRO3 are within the range of variation from 36\% to 50\% for NDF, cited by Oliveira et al. (2002), and from 18\% to $26 \%$ for ADF, cited by Nussio (1991).

Regarding phosphorous, calcium and potassium contents in the silages, the hybrid AGZ7210 PRO2 stood out for its accumulation of phosphorus and calcium (Figure 7A), while the silage produced from the hybrid BM3077 PRO3 had higher potassium accumulation (Figure 7B), highlighting the difference of response between corn materials in terms of increment in nutrient contents and, therefore, nutritional value of the silage. 
Figure 5. Dry matter of the silage from different corn hybrids. *Means followed by equal letters on bars do not differ from each other by Tukey test at $5 \%$ probability level.

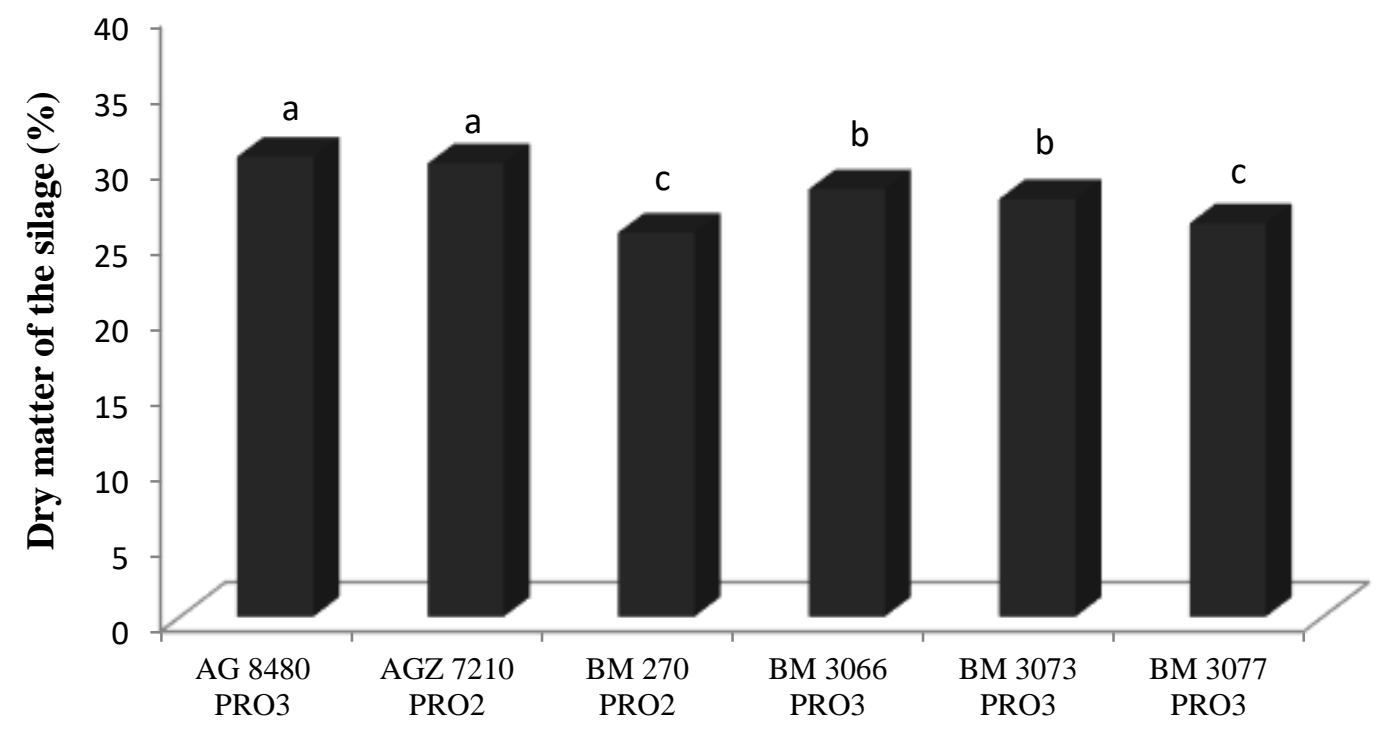

Source: Authors. 
Figure 6. Mineral matter, crude protein and N-NH3/TN (A) and NDF and ADF (B) of the silage from different corn hybrids. *Means followed by equal letters on bars do not differ from each other by Tukey test at $5 \%$ probability level.
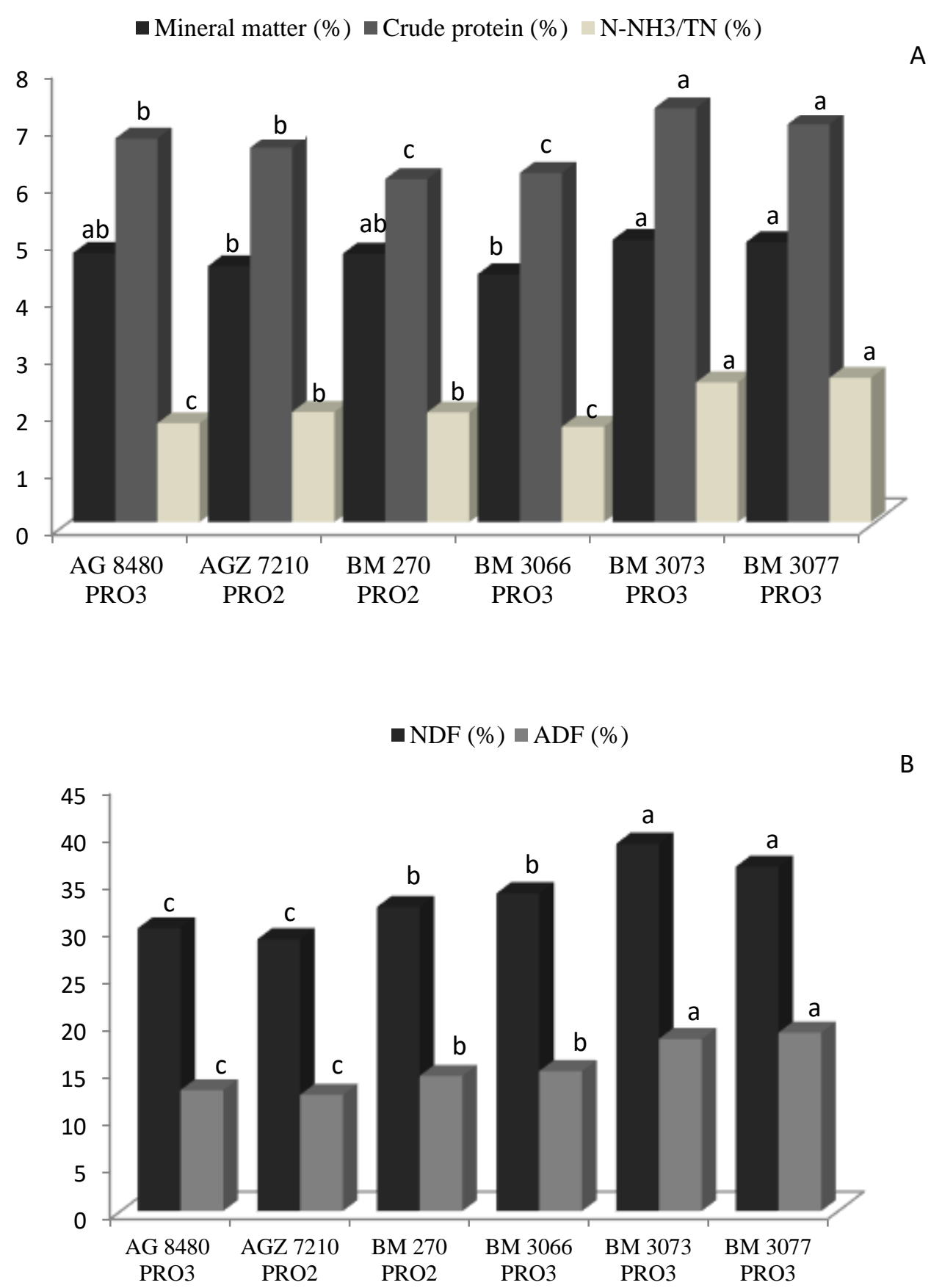

Source: Authors. 
Figure 7. Phosphorus and calcium (A) and potassium (B) contents in the dry matter of the silage from different corn hybrids. *Means followed by equal letters on bars do not differ from each other by Tukey test at $5 \%$ probability level.
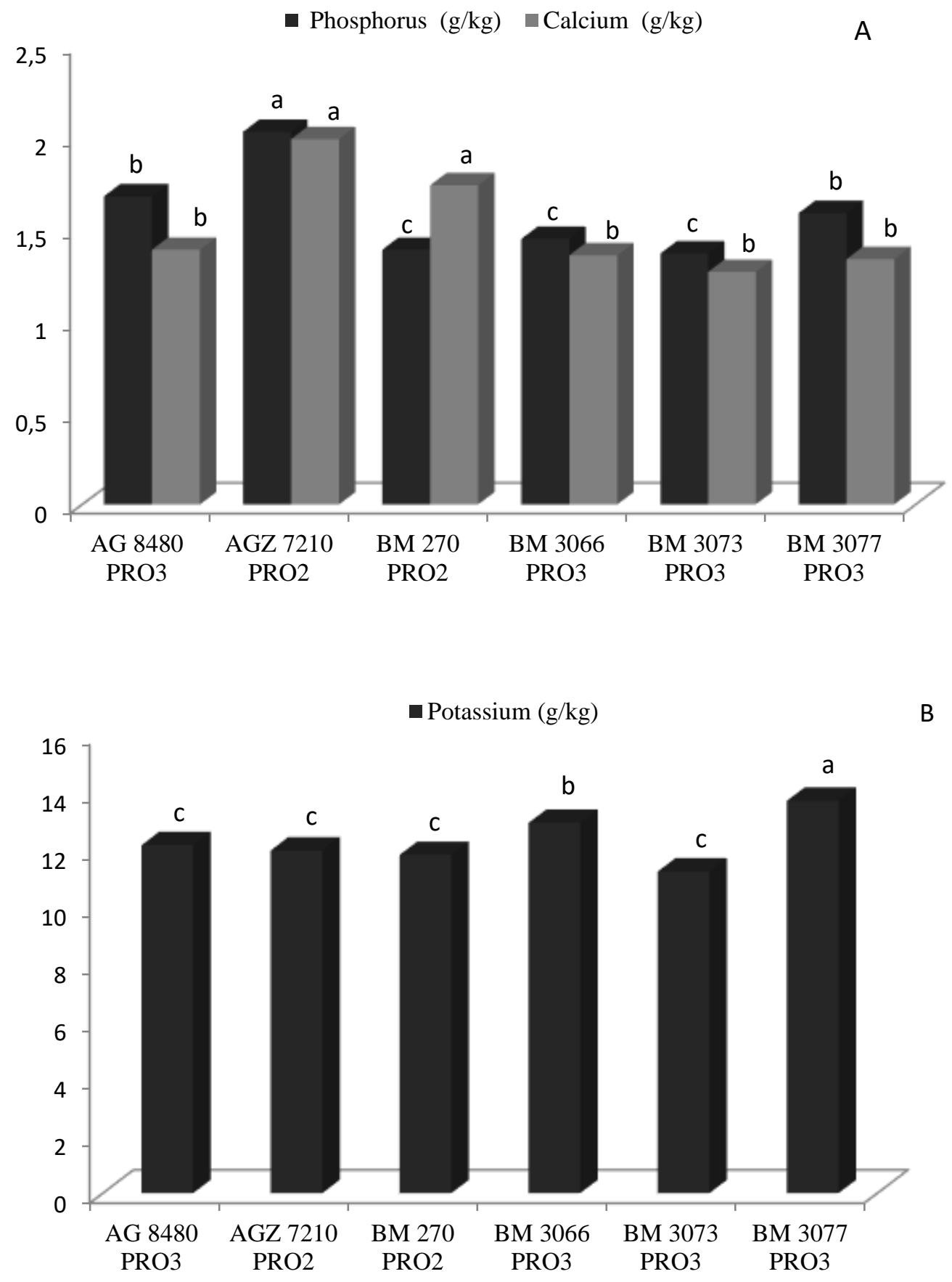

Source: Authors. 
Lignin is one of the main factors that limits the degradability of the cell wall (VAN SOEST, 1994), reflecting a longer time for rumen emptying and lower silage consumption, with common levels between 1 and $4 \%$. In the present work, the lignin content of silages produced from the different corn hybrids ranged from $2 \%$ to $3.9 \%$. The silages produced from the hybrids BM270 PRO2 and BM3066 PRO3 were statistically higher $(\mathrm{p}<0.05)$ than the other silages (Figure 8A), and the lignin contents were within the standard established by the literature. While for starch contents there was statistical difference only for silage produced from hybrid BM 3077 PRO3, with the lowest starch accumulation values in silage. These data confirm the direct relationship between the harvest point and the lignin and starch contents in silage, since with $2 / 3$ of the milk line there is the highest starch accumulation and the lowest fiber content in corn silage.

Figure 8. Lignin (A) and Starch (B) of the silage from different corn hybrids. *Means followed by equal letters on bars do not differ from each other by Tukey test at $5 \%$ probability level.
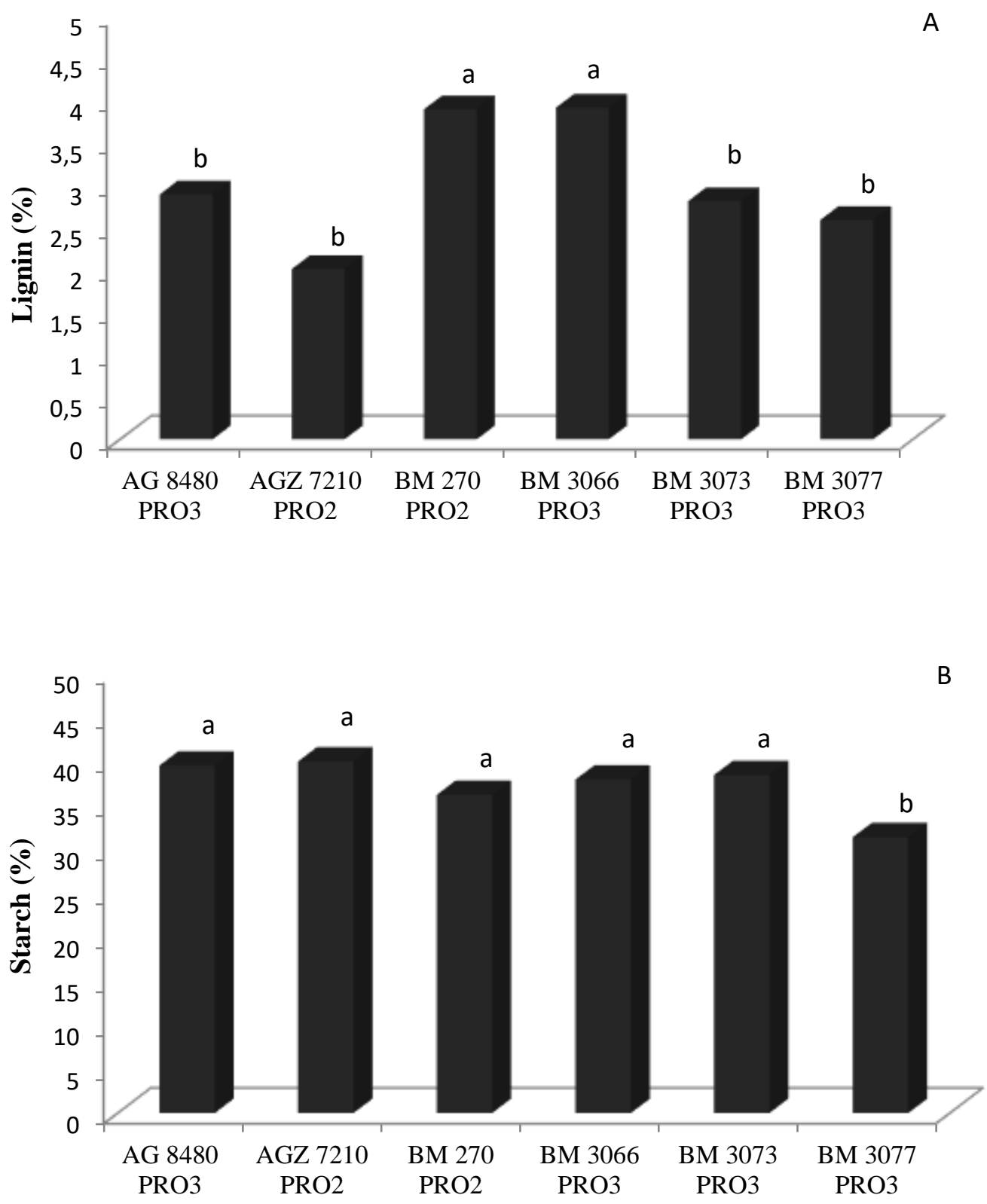

Source: Authors. 


\section{Discussion}

\section{Agronomic performance of corn hybrids}

The variation of the results regarding the morphological characteristics of the plants, such as plant height and ear attachment height is attributed to the hybrids' genetics itself, which causes some of them to be taller and others to be shorter, noting that taller plants also had the highest ears.

Stem diameter varied between 20.66 and $23.66 \mathrm{~mm}$, which makes it possible to infer that these values were sufficient to avoid breakage and/or lodging of the plants, since Zucareli et al. (2013) related greater lodging and breaking of plants to the smaller development of the stem. Distinct results for stem diameter among the evaluated hybrids have also been reported by other authors (Kappes et al. 2011; Hanashiro et al. 2013 and Araújo et al. 2016).

In the evaluation of the production components, the results reveal that for the hybrid with the longest ear, the length was $21.58 \%$ greater than that of the hybrid with the shortest ear and that for the hybrid with thickest ear base, the diameter was $12.44 \%$ larger than that of hybrid with the thinnest ear base. It must be pointed out that the length of the ear influences the number of grains present in it and, consequently, both influence the amount of grains per area. These two characteristics are strongly influenced by genetics; however, depending on the stage of plant development, they may be highly sensitive to climatic variations (Bastos, 2019). These critical stages are from V5 to V8, when the potential number of grain rows is determined, and from V12 to V15, when the potential number of grains in each row is defined. In the studies conducted by Vilela et al. (2012) and Araújo et al. (2016), these authors observed variations in this production component as a function of the hybrid.

As for fresh matter yields, this information is important and useful, as it serves as a parameter for the producer to define the size their silos; however, in the selection of corn cultivars for silage production, not only biomass production should be taken into account (Ferrari Júnior et al. 2005). Fresh matter yield is a variable that is directly affected by the height at which plants are cut and by the vegetative cycle, which makes it complex and dynamic compared with the results of studies that have worked with cutting heights and production cycle different from those adopted in the present study. Neumann et al. (2018) report that the hybrid that has the highest grain production combined with a good percentage of leaves is able to result in a silage with significant energy and fermentative quality, considering the influence of carbohydrates on the fermentation process. Paziani et al. (2009) also found a positive correlation between plant height and higher fresh matter production and between height and better digestibility of stem and whole plant in taller plants, in addition to dry matter yield above 50 t/ha. Klein et al. (2018) observed that taller corn hybrids with longer cycles tend to produce silage with higher proportion of fibrous material, while earlier and shorter hybrids have the potential to produce silage with a higher percentage of ear and grains.

It must be highlighted that the variations in the results related to the production components among the different hybrids cultivated can be explained by numerous factors, especially the quality of the germplasm relative to the strains used, adaptation to the region of cultivation, technological level, management practices adopted, production potential of the hybrid (Araújo et al. 2016) and its environmental conditions, mainly water, nitrogen, leaf integrity and radiation absorption efficiency (Fumagalli et al. 2017).

The production of ruminants depends, among other factors, on the quality of the feed, which provides the nutrients required to meet the nutritional needs of both ruminants and rumen microorganisms. Thus, the ideal forage plant should contain as much nutrients as possible in its composition, as well as yielding a large amount of forage mass per unit of area. Therefore, the grain/fresh matter ratio and DM production are important factors of adaptability of a hybrid for silage production, but knowledge on the nutritional composition of corn for silage is an equally important criterion that should be taken into account in the selection of hybrids for silage (Bendia, 2018). 
The results of the study confirm the distinction of response between corn cultivars in terms of nutrient increment during the development cycle of the hybrids and remobilization from the shoots to the reproductive part of the plant, especially to the grains, and this difference is due to the genetic variations existing among the corn hybrids. Ritchie et al. (2003) describe that, in relation to the total $\mathrm{N}$ absorbed by the plants, in the physiological maturity stage, approximately $65 \%$ is found in the grains and $35 \%$ in the shoots; for P, approximately $75 \%$ is concentrated in the grains $25 \%$ in the shoots; while for $\mathrm{K}$ and $\mathrm{Ca}$, unlike the other elements, the highest contents are present in the vegetative structure of the plant, with approximately $35 \%$ concentrated in the grains. Thus, based on these data, the average extractions of N, P and Ca by the shoots (without ear) of the different corn hybrids are on the order of $38 \mathrm{~kg} / \mathrm{ha}$ of $\mathrm{N}, 2.46 \mathrm{~kg} / \mathrm{ha}$ of $\mathrm{P}$ and $31.93 \mathrm{~kg} / \mathrm{ha}$ of Ca, which made it possible to determine that the total accumulations of $\mathrm{N}, \mathrm{P}$ and $\mathrm{Ca}$ in the shoots were $108 \mathrm{~kg} / \mathrm{ha}, 9.84 \mathrm{~kg} / \mathrm{ha}$ and $49.13 \mathrm{~kg} / \mathrm{ha}$, respectively. It is evident that, with the development of the ear, there is a reduction in the proportion of nutrients accumulated in the other organs of the plant.

\section{Chemical composition of silage}

Menezes et al. (2013) already emphasized that silage quality is as important as yield, since the higher the nutritional quality of the forage, the lower the cost of the concentrate used. The $\mathrm{pH}$ means of the silages from the different corn hybrids were on the order of 3.76, and acidity is considered an important factor in silage conservation, as it acts by inhibiting or controlling the development of harmful microorganisms, such as bacteria of the genus Clostridium, which are sensitive to $\mathrm{pH}$ lower than 4 (Oliveira et al. 2002). However, the average $\mathrm{pH}$ values found in the present study are within the range suggested as adequate for good quality silages, that is, low enough to inhibit undesirable microbial activity in the silage. Similar results were obtained by Buso et al. (2018), who evaluated chemical-bromatological composition of silage from five corn hybrids at two cuttings heights and found that $\mathrm{pH}$ value of 3.69 promoted efficient conservation of the ensiled mass.

The mean DM contents in the silage ranged between $25 \%$ and 30\%, being in general below the recommended, since for corn the dry matter content in the silage should be between 30 and $35 \%$, more than $3 \%$ of soluble carbohydrates in the original matter and low buffering power (Neumann et al. 2013). However, the mean $\mathrm{pH}$ value of the silages was below 4.0, with no losses of liquids in these silages, making it possible to affirm that there was availability of sufficient soluble carbohydrates for an adequate fermentation, a factor that is necessary for the interruption of undesirable fermentation processes and the consequent preservation of silage, especially those with DM contents below 30\% (Neumann et al. 2002; Nascimento et al. 2008; Pires et al. 2013). This result can be attributed to the greater number of green leaves present in the plant at the time of harvest and/or to the harvest performed just before the ideal time of grain maturity recommended for silage, since in the present experiment a single time was adopted for cutting the plants, which may have favored the variations found in DM contents, because there are hybrids with different vegetative cycles. Araújo et al. (2012) evaluated the silage from six corn hybrids and found that there was no significant difference in DM contents between silages, whose contents ranged from 28.8 to $34.5 \%$.

As for the contents of mineral matter (MM), crude protein (CP) and N-NH3/TN in the silages, the results indicate that the silage quality is very good, since Roth and Undersander (1995), characterizing the typical fermentation profile of wellprepared corn silages, stated that N-NH3/TN levels should be below $5 \%$, and those found in the study were on the order of $2 \%$, while the protein level of corn silage should be within the range between $6 \%$ and $9 \%$, as a minimum amount of $\mathrm{N}$ is required by rumen microorganisms, despite the exception that excess crude protein can lead to undesirable fermentation conditions in the silo (Van Soest, 1994). Thus, differences between hybrids in terms of CP content are observed in the literature; however, they are not always easily detected or are very small and may even be related to differences in the efficiency of absorption of the $\mathrm{N}$ available in the soil for the plant, since the various hybrids and varieties require different amounts of $\mathrm{N}$, according to 
their yield potential (Fernandes et al. 2005). Corroborating these results, Buso et al. (2018) and Ribeiro et al. (2017), when analyzing N-NH3/TN data from the liquid fraction of silages from different corn hybrids, observed mean values on the order of 1.89 and $1.90 \mathrm{mg} / \mathrm{mL}$, respectively, which show that fermentation was well performed by microorganisms, maintaining silage quality.

The contents of neutral detergent fiber (NDF) and acid detergent fiber (ADF) were within the ideal range to stimulate the DM consumption by the animal. The former represents the total amount of fiber of the feed, which is negatively correlated with DM consumption, that is, the higher this value, the lower the intake, because the fiber ferments more slowly and remains for longer periods in the rumen than other components of the feed, while ADF represents lignin and cellulose, compounds of low ruminal digestibility, so that the low content of ADF is desirable for a good quality silage, being positively correlated with the energy value of the silage; the lower the ADF, the higher the energy value. Therefore, if DM production is not compromised, hybrids with lower contents of fiber, lignin and cellulose, represented by NDF and ADF, should be chosen for the ensilage process, aiming to produce silage of greater digestibility and quality, since these characteristics are directly related to the speed of passage of food through the digestive tract, DM consumption and energy value.

\section{Conclusions}

There was variation in the agronomic performance of commercial corn hybrids for the southern region of Rondônia.

The silages produced from the six corn hybrids showed bromatological and chemical characteristics that characterize them as silages of very good quality, despite having significant differences in the percentages of dry matter, mineral matter, crude protein, N-NH3/TN, neutral detergent fiber and acid detergent fiber.

The hybrid BM3073 PRO3 stood out in terms of fresh matter yield, N content in the shoots and quality of the silage produced, which may result in reduction of silage production costs.

\section{Acknowledgments}

The authors thank the Federal Institute of Rondonia and the Department of Research, Innovation and Graduate Studies of the Colorado do Oeste Campus for providing resources, research stipend and a financial aid for translation and publication through the Calls No. 13/2020/COL and No. 08/2021/COL.

\section{References}

Araujo, L. S., Silva, G. B., Silveira, P. M., Rodrigues, F., Lima, M. L. P., \& Cunha, P. C. R. (2016). Desempenho agronômico de híbridos de milho na região sudeste de Goiás. Revista Agro@mbiente On-line, 10(4), 334-341. 10.18227/1982-8470ragro.v10i4.3334

Association of oficial analytical chemist - AOAC. (1995). Official methods of analysis 16.ed. Washington, D.C., 1094p.

Bastos, M. S. (2019). Características agronômicas de híbridos de milho para produção de silagem cultivados em quatro estados brasileiros. 68, Dissertação (Mestrado em Zootecnia) - Universidade Federal de Lavras.

Bendia, L. C. R. (2018). Avaliação nutricional de híbridos de milho para a ensilagem. 60, Dissertação (Doutorado em Ciência Animal) - Universidade Estadual do Norte Fluminense Darcy Ribeiro.

Bernardes, T. F., \& Do Rêgo, A. C. (2014). Study on the practices of silage production and utilization on Brazilian dairy farms. Journal of Dairy Science, 83, 1264- 1273. https://doi.org/10.3168/jds.2013-7181

Buso, W. H. D., Machado, A. S., Ribeiro, T. B., Silva, L. O. (2018). Produção e composição bromatológica da silagem de híbridos de milho sob duas alturas de corte. Revista de Agricultura Neotropical, 5(4), 74-80. https://doi.org/10.32404/rean.v5i4.2682

Conab (2021). Acompanhamento da Safra Brasileira de Grãos 2020/2021: Oitavo Levantamento, Maio/2021, Companhia Nacional de Abastecimento. Brasília, CONAB, 8(8), 115.

Empresa Brasileira de Pesquisa Agropecuária - Embrapa (2009). Manual de análises químicas de solos, plantas e fertilizantes.- 2. Ed, Brasília., Embrapa Informação Tecnológica, 627 p. 
Fernandes, F. C. S., Buzetti, S., Arf, O., \& Andrade, J. O. C. (2005). Doses, eficiência e uso de nitrogênio por seis cultivares de milho. Revista Brasileira de Milho e Sorgo, 4(2), 195-204. https://doi.org/10.18512/1980-6477/rbms.v4n02p\%25p

Ferrari Júnior, E., Possenti, R. A., Lima, M. L. P., Nogueira, J. R., \& Andrade, J. B. (2005). Características agronômicas, composição química e qualidade de silagens de oito cultivares de milho. B. Indústr. Anim., 62(1),19-27. http://www.iz.sp.gov.br/pdfsbia/1180030929.pdf

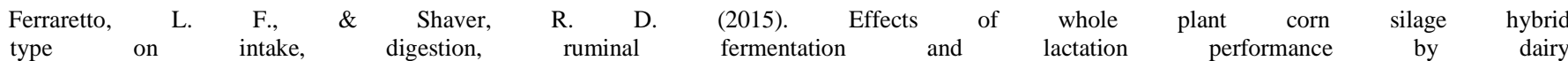
cows through a meta-analysis. Journal of Dairy Science, 98, 2662-2675. https://doi.org/10.3168/jds.2014-9045

Fumagalli, M., Fiorini, I. V. A., Machado, R. A. F., Pereira, H. D., Pereira, C. S., Pires, L. P. M., \& Resende, F. R. (2017). Desempenho produtivo do milho híbrido simples em função de espaçamentos entre fileiras e populações de plantas. Revista Brasileira de Milho e Sorgo, 16(3), 426-439. https://doi.org/10.18512/1980-6477/rbms.v16n3p426-439

Goering, H. K., \& Van Soest, P. J. (1970). Forage fiber analysis: apparatus reagents, procedures and some applications. Agricultural Handbook, 379. Washington, DC.

Gralak, E., Faria, M. V., Júnior, O. M., Rossi, E. S., Silva, C. A., Rizzaedi, D. A., Mendes, M. C., \& Neumann, M. (2014). Capacidade combinatória de híbridos de milho para caracteres agronômicos e bromatológicos da silagem. Revista Brasileira de Milho e Sorgo, 13(2), 187-200, https://doi.org/10.18512/1980-6477/rbms.v13n2p187-200

Hanashiro, R. K., Mingotte, F. L. C., \& Fornasieri Filho, D. (2013). Desempenho fenológico, morfológico e agronômico de cultivares de milho em Jaboticabal-SP. Científica, 41, 226-234. http://dx.doi.org/10.15361/1984-5529.2013v41n2p226-234

Kappes, C., Andrade, J. A. C., Arf, O., Oliveira, A. C., Arf, M. V., \& Ferreira, J. P. (2011). Desempenho de híbridos de milho em diferentes arranjos espaciais de plantas. Bragantia, v. 70, 334-343. https://doi.org/10.1590/S0006-87052011000200012

Klein, J. L., Viana, A. F. P., Martini, P. M., Adams, S. M., Guzatto, C., Bona, R. A., Rodrigues, L. S., Filho, D. C. A., \& Brondani, I. L. (2018). Desempenho produtivo de híbridos de milho para produção de silagem da planta inteira. Revista Brasileira de Milho e Sorgo, 17(1), 101 110. https://doi.org/10.18512/1980-6477/rbms.v17n1p101-110

Menezes, L. F. G., Ronsani, R., Pavinato, P., \& Biesek, R. R. (2013). Produção, valor nutricional e eficiências de recuperação e utilização do nitrogênio de silagens de milho sob diferentes doses de adubação nitrogenada. Semina: Ciências Agrárias, 34(3), 1353-1362. 10.5433/1679-0359.2013v34n3p1353

Moraes, S. D., Jobim, C. C., Silva, M. S., \& Marquardt, F. F. (2013). Produção e composição química de híbridos de sorgo e de milho para silagem. Revista Brasileira de Saúde e Produção Animal, 14(4), 624-634. https://www.scielo.br/j/rbspa/a/fkjFCL4XfqZfZjWNbBykjhs/?format=pdf\&lang=pt.

Nascimento, W. G.,Prado, I. N., Jobim, C. C., Emile, J. C., Surault, F., \& Huyghe, C. (2008). Valor alimentício das silagens de milho e de sorgo e sua influência no desempenho de vacas leiteiras. Revista Brasileira de Zootecnia, 37(5), 896-904.https://doi.org/10.1590/S1516-35982008000500018

Neumann, M., Poczynec, M., Leão, G. F. M.,Figueira, D .N., \& Souza, A. M. (2018). Desempenho de híbridos de milho para silagem cultivada em diferentes locais com três densidades populacionais. Revista Brasileira de Milho e Sorgo, 17(1), 42-62. https://doi.org/10.18512/1980-6477/rbms.v17n1p49-62

Neumann, M., Marafon, F., \& Ueno, K. R. (2013). Eficiência de confecção da silagem de milho: processamento de grãos e tamanho de partícula. Informe Agropecuário, 34(277), 7-18.

Neumann, M., Restle, J., Alves Filho, D. C., Brondani, I. L., Pellegrini, L. G., \& Freitas, A. k. (2002). Avaliação do valor nutritivo da planta e da silagem de diferentes híbridos de sorgo (Sorghum bicolor, (L.) Moench). Revista Brasileira de Zootecnia, 31(1), 293-301. https://doi.org/10.1590/S151635982002000200002

Nussio, L.G. (1991). Cultura de milho para produção de silagem de alto valor alimentício. In: SIMPÓSIO SOBRE NUTRIÇÃO DE BOVINOS, 4., 1991, Piracicaba. Anais. Piracicaba: Escola Superior de Agricultura Luiz de Queiroz, p. 59-168.

Oliveira, M. D. S., Souza, B. A. C., \& Torres, R. (2002). Composição químico bromatológica de onze cultivares de milho. ARS Vet., 18(2),158-166.

Paziani, S. F.,Duarte, A. P., Nussio, L. G., Gallo, P. B., Bittar, C. M. M., Zopollatto, M., \& Reco, P. C. (2009). Características agronômicas e bromatológicas de híbridos de milho para produção de silagem. Revista Brasileira de Zootecnia, 38(3), 411- 417. https://doi.org/10.1590/S1516-35982009000300002

Pereira Filho, I. A., \& Borghi, E. (2016). Mercado de sementes de milho no Brasil: safra 2016/2017. Embrapa Milho e Sorgo - Documentos (INFOTECA-E). Disponível em: https://ainfo.cnptia.embrapa.br/digital/bitstream/item/155505/1/doc202-1.pdf

Pires, D., Rocha Júnior, V. R., Sales, E. C. J., Reis, S. T., Jayme, D. G., Cruz, S. S., Lima, J. O. B., Tolentino, D. C., \& Esteves, B. L. (2013). Características das silagens de cinco genótipos de sorgo cultivados no inverno. Revista Brasileira de Milho e Sorgo, 12(1), 68-77. https://doi.org/10.18512/19806477/rbms.v12n1p68-77

Ritchie, S. W., \& Hanway, J. J., Benson, G. O. (1993). How a corn plant develops. Iowa State Univ. Coop. Ext. Serv. Spec. Rep, 48, 21.

Ribeiro, T. B., Buso, W. H. D., Silva, L. O., Oliveira, H. P., \& Machado, A. S. (2017). Produtividade e caracterização químico-bromatológica de híbridos de milho em duas alturas de corte. Nutritime Revista Eletrônica, 14(1), 4928-4935. https://www.nutritime.com.br/site/wp-content/uploads/2020/02/Artigo407.pdf

Roth, G., \& Undersander, D. (1995). Silage additives. In: Corn silage production management and feeding Madison: Madison American Society of Agronomy, 27-29. Disponível em: https://pennstate.pure.elsevier.com/en/publications/corn-silage-production-management-and-feeding-2. 
Research, Society and Development, v. 10, n. 12, e320101220572, 2021

(CC BY 4.0) | ISSN 2525-3409 | DOI: http://dx.doi.org/10.33448/rsd-v10i12.20572

Santos, G., Moraes, J. M. M., \& Nussio, L. G. (2017). Custo e análise de sensibilidade na produção de silagem. Revista iPecege. 2017, 3(1), 39-48. https://doi.org/10.22167/r.ipecege.1.39.

Silva, D. J., \& Queiroz, A. C. (2006). Análise de Alimentos: métodos químicos e biológicos. 3 ed. Viçosa: UFV, 235 p.

Van Soest, P. J. (1994). Nutritional ecology of the ruminant. 2. ed. Ithaca: Cornell University, Ithaca, 476 p.

Vilela, R. G., Arf, O., Kappes, C., Kaneko, F. H., Gitti, D. C., \& Ferreira, J. P. (2012). Desempenho agronômico de híbridos de milho, em função da aplicação foliar de fungicidas. Bioscience Journal, 28, 25-33. http://www.seer.ufu.br/index.php/biosciencejournal/article/view/11672.

Zucareli, C., Oliveira, M. A., Spolaor, L. T., \& Ferreira, A. S. (2013). Desempenho agronômico de genótipos de milho de segunda safra na região Norte do

Paraná. Scientia Agraria Paranaensis, 12, 227- 235. https://doi.org/10.18188/sap.v12i3.5593 